Original Research Paper

\title{
Pendampingan Tata Kelola Keuangan Badan Usaha Milik Desa
}

\author{
Lilik Handajani' ${ }^{1}$ Akram $^{2}$, Saipul Arni Muhsyaf ${ }^{2}$, Ayudia Sokarina ${ }^{4}$ \\ ${ }^{\text {I} P r o g r a m ~ S t u d i ~ M a g i s t e r ~ A k u n t a n s i ~ F a k u l t a s ~ E k o n o m i ~ d a n ~ B i s n i s, ~ U n i v e r s i t a s ~ M a t a r a m, ~ M a t a r a m, ~ I n d o n e s i a ; ~}$
}

https://doi.org/10.29303/jpmpi.v3i2.1127

Sitasi: Handajani, L., Akram., Muhsyaf, S. A \& Sokarina. A. (2021). Pendampingan Tata Kelola Keuangan Badan Usaha Milik Desa. Jurnal Pengabdian Magister Pendidikan IPA 4(4)

Article history

Received: 02 Oktober 2021

Revised: 20 Oktober 2021

Accepted: 07 November 2021

*Corresponding Author: Lilik

Handajani, University of

Mataram, Mataram, Indonesia; Email:

lilikhandajani@unram.ac.id

\section{Pendahuluan}

$\mathbf{B}_{\text {salah satu program ungulan dalam }}^{\text {adan Usaha Milik Desa (BUMDes) merupakan }}$ undang tentang Desa pada tahun 2014 memberikan kewenangan bagi desa melalui dana desa dalam mengalokasikan sumberdaya keuangannya untuk pemberdayaan ekonomi desa, yang salah satunya melalui melalui pembentukan badan usaha milik

\begin{abstract}
The main problem in managing village-owned enterprises (known as BUMDes) is the sustainability of economic enterprises after BUMDes is formed. Many BUMDes are then inactive after being formed due to problems in their management. Problems with procedures in financial management are indicated as the main factor causing problems in the management of BUMDes in addition to other factors such as the limited ability of BUMDes managers and lack of supervisory functions. Most BUMDes managers have limited knowledge, understanding, and abilities in administering and reporting business finances. This condition will certainly be an obstacle to business continuity and the continuous progress of BUMDes as a productive economic business in the village which is expected to support the welfare of the village community. This partnership community service activity is carried out through a pattern of mentoring assistance to BUMDes managers in Peteluan Indah Village who are still experiencing problems in administering and reporting BUMDes finances due to limited knowledge and human resource capabilities of BUMDes managers. This assistance activity is carried out through an evaluation of the institutional aspects, business management and financial management of BUMDes. The results of this mentoring activity provide a strengthening of the organizational structure related to the duties, functions and authorities of BUMDes managers, advisors and supervisors. From the aspect of business management, this activity can direct the management of existing BUMDes businesses and identify other economic business opportunities according to the superior potential of the village. From the aspect of financial governance, this mentoring activity can evaluate weaknesses and problems in the pattern of financial management through financial administration and reporting that are needed to support financial accountability and transparency to realize best practices in BUMDes financial governance.
\end{abstract}

Keywords: BUMDes, financial governance, tranparency, accountability

desa (BUMDES). Data Kementerian Desa, Pembangunan Daerah Tertinggal, dan Transmigrasi (Kemendesa PDTT) menyatakan sampai akhir tahun 2018, sebanyak 61 persen desa telah memiliki BUMDes atau telah terbentuk 45.549 unit BUMDes di Indonesia, dan jumlah ini meningkat dari jumlah BUMDes pada tahun 2014 yang hanya sejumlah 1.022 (Nasruhaq, 2019). Di Provinsi Nusa Tenggara Barat, data Badan Pemberdayaan Masyarakat dan Pemerintahan Desa (BPMPD) 
Provinsi Nusa Tenggara Barat menyatakan bahwa dari sebanyak 955 desa di 10 kabupaten/kota hanya 422 desa yang memiliki BUMDEs dan BUMDes yang aktif hanya 222 (Ridwan \& Puti, 2016). Kondisi ini ditengarai karena pengelolaan BUMDes yang masih kurang bagus, sebagian besar BUMDes bergerak di usaha simpan pinjam dan bukan di sektor usaha, dana yang dikelola relatif rendah, serta kemampuan jiwa usaha pengelola yang rendah dan fungsi pengawasan yang kurang.

Regulasi terbaru dalam Permendesa dan PDTT No 13 Tahun 2020 tentang Prioritas Penggunaan Dana Desa Tahun 2021 secara eksplisit menyatakan bahwa penggunaan dana desa harus diprioritaskan untuk penguatan segala bentuk kegiatan ekonomi desa dan peningkatan kualitas sumber daya manusia untuk membangun ekonomi kreatif dengan memanfaatkan semua peluang di desa. Salah satu elemen penting dalam penguatan perekonomian desa adalah melalui pengembangan BUMDes yang didukung oleh kemampuan sumberdaya pengelola dalam menjalankan usaha BUMDes. Implementasi regulasi ini perlu didukung pengelolaan BUMDes dan kapasitas pengelola yang memiliki kemampuan manajemen usaha dan pengelolaan keuangan yang baik. Namun demikian sebagian BUMDes mengalami permasalahan dalam pengelolaannya. Dari 45.549 BUMDes yang ada di desa-desa Indonesia sebanyak $90 \%$ belum dapat berjalan dengan baik, yang diindikasikan karena masalah prosedur pengelolaan keuangan BUMDes (Resti, 2019). Studi Agunggunanto dkk. (2016) pada BUMDes di Kabupaten Jepara mengungkapkan banyak desa yang gagal menjalankan BUMDes karena kurang siapnya desa dan minimnya potensi yang dimiliki desa, terutama berkaitan dengan keterbatasan jenis usaha yang dijalankan, pengetahuan dan kemampuan pengelola BUMDes serta partisipasi masyarakat yang rendah. Sejalan dengan temuan sebelumnya hasil penelitian Titioka dkk. (2020) menyatakan dalam pengelolaan BUMDEs diperlukan ketrampilan dan komitmen penerapan tata kelola laporan keuangan sesuai siklus akuntansi karena masih rendahnya pengetahuan dan ketrampilan aparatur pemerintah desa dan pengelola BUMDes tentang tata kelola BUMDes yang baik, akuntabel dan transparan. Dari aspek pengawasan, studi Oktaviani \& Nuswantara (2020) pada BUMDes di Kabupaten Sidoarjo menyatakan bahwa tingkat implementasi prinsip-prinsip pengendalian internal pada BUMDes masih rendah. Hal ini mengimplikasikan bahwa tata kelola keuangan BUMDes menjadi faktor krusial keberhasilan pengelolaan BUMDes. Oleh karena itu pengelolaan BUMDes harus transparan dan berorientasi pada proses serta dikelola secara profesional oleh SDM kompeten yang memiliki kemampuan dan keahlian dalam bidang akuntansi (Musafa, Hernawan \& Dewi, 2018). BUMDES merupakan kunci kekuatan perekonomian desa sehingga harus dikelola dengan penuh tanggung jawab karena BUMDes adalah bentuk usaha yang dimiliki oleh seluruh masyarakat desa, dan bukan hanya perorangan atau kelompok tertentu. Dengan pengelolaan potensi ekonomi dan alokasi sumberdaya dengan tepat maka dapat meningkatkan kesejahteraan masyarakat desa. Hasil penelitian Dwiningwarni \& Amrulloh (2020) mendukung argumentasi tersebut bahwa keberadaan BUMDes sangat diperlukan oleh masyarakat dan alokasi dana desa untuk program pemberdayaan melalui BUMDes dapat meningkatkan kesejahteraan masyarakat.

Salah satu kunci keberhasilan pengelolaan BUMDes adalah tata kelola keuangan. Melalui tata kelola keuangan yang baik maka BUMDes menjadi lembaga ekonomi desa yang transparan dan akuntabel dalam memberikan pertanggungjawaban sehingga akan didukung oleh masyarakat desa. Kesulitan dalam pengelolaan keuangan BUMDes menjadi permasalahan pada sebagian besar BUMDes yang ada, tidak terkecuali BUMDes pada Desa Peteluan Indah yang berada di Kecamatan Lingsar Kabupaten Lombok Barat. Berdasarkan hasil survei awal menunjukkan bahwa pengelola BUMDes hanya melakukan pengelolaan keuangan secara umum seperti pencatatan kas dan pelaporan dengan cara sederhana. Meskipun tata cara seperti ini dianggap sebagai hal yang umum dan sudah biasa dilakukan, maka akan sulit untuk dapat melakukan evaluasi terhadap kinerja dan hasil usaha BUMDes maupun tindakan pengawasannya karena terbatasnya dokumen pendukung yang dapat diverifikasi untuk pertanggungjawaban pengelolaan keuangan BUMDes. Sesuai dengan Permendesa PDTT Nomor 4 Tahun 2015 pengelolaan BUMDes harus mencakup 4 tahapan yaitu penganggaran, 
penatausahaan, pelaporan dan pengendalian internal. Tujuannya agar BUMDes yang dimiliki oleh masyarakat desa menjadi akuntabel dan transparan dalam pengelolaannya serta dapat dievaluasi kinerjanya sehingga dapat berkembang menjadi usaha ekonomi masyarakat desa yang semakin maju. Pertanggungjawaban pengelolaan keuangan BUMDes memerlukan penatausahaan dan pelaporan keuangan yang transparan dan akuntabel. Adanya laporan keuangan BUMDes akan membantu mencerminkan kondisi keuangan usaha dan berperan dalam membantu pengambilan keputusan di masa mendatang (Irawati \& Martanti, 2017). Untuk menunjang tercapainya tujuan tersebut maka diperlukan upaya-upaya untuk mendampingi pengelola BUMDes pada desa Peteluan Indah dalam melakukan dan memperbaiki tata kelola keuangan BUMDes menjadi lebih baik sejalan tujuannya untuk pemberdayaan ekonomi desa dan peningkatan kesejahteraan masyarakat desa.

Kegiatan pengabdian masyarakat Kemitraan ini bertujuan untuk: (1) memberikan pengetahuan dan pemahaman bagi pengelola Badan Usaha Milik Desa (BUMDes) tentang pentingnya tata kelola keuangan dalam menjalankan usaha BUMDes agar kinerja BUMDes dapat dievaluasi, (2) merancang kebutuhan dokumen keuangan yang diperlukan dalam penatausahaan dan pelaporan usaha BUMDes, seperti pencatatan transaksi sesuai dengan kaidah akuntansi, penyusunan laporan arus kas, laporan hasil usaha dan laporan posisi keuangan BUMDes; dan (3) mendampingi pengelola BUMDes dalam mengimplementasikan kegiatan penatausahaan dan pelaporan keuangan sehingga pada akhirnya pengelola BUMDes menjadi mandiri dalam menerapkannya. Hasil kegiatan pengabdian kemitraan ini dapat memberikan kontribusi bagi pengelola BUMDes dan pemangku kepentingan desa (Kepala desa dan perangkat desa, Badan Permusyawaratan Desa/BPD dan masyarakat pada umumnya) dapat memiliki pengetahuan dan pemahaman yang baik tentang best practices pengelolaan BUMDes sesuai ketentuan yang berlaku. Melalui kegiatan pendampingan kepada pengelola BUMDes, dapat dirancang dokumen penatausahaan dan pelaporan usaha BUMDes sehingga dapat digunakan sebagai mekanisme evaluasi terhadap keberhasilan usaha
BUMDes dan tindakan pengawasan yang diperlukan. Pada akhirnya hasil kegiatan pendampingan tata kelola keuangan BUMDes dapat ditindaklanjuti dan dilaksanakan secara mandiri oleh pengelola BUMDes sehingga menjadi usaha pemberdayaan ekonomi desa yang transparan dan akuntabel.

\section{Metode}

Kegiatan pengabdian kemitraan ini dilakukan pada Desa Peteluan Indah Kecamatan Lingsar Kabupaten Lombok Barat selama periode Mei September 2021. Kegiatan pengabdian masyarakat ini dilakukan dengan tahapan sebagai berikut:

1. menginformasikan kepada Kepada Desa dan pengelola BUMDes di Desa Peteluan Indah tentang tujuan kegiatan pengabdian masyarakat kemitraan untuk membantu dan mendampingi pengelola BUMDes dalam melaksanakan tata kelola keuangan yang tepat sesuai ketentuan yang berlaku.

2. melakukan pertemuan pendahuluan dalam suatu forum diskusi informal dengan kepala desa dan pengelola BUMDes sehingga diperoleh pemahaman dan persepsi yang sama tentang tujuan dari kegiatan pengabdian kemitraan.

3. melakukan pertemuan dan interview awal secara mendalam dengan kepala desa dan pengelola BUMDes tentang jenis usaha ekonomi yang dijalankan BUMDes, pola pengelolaan keuangan, pencatatan dan pelaporan yang selama ini dilakukan sehingga diperoleh gambaran secara lengkap tentang kelemahan dan permasalahan yang ada dalam pengelolaan keuangan BUMDes saat ini.

4. mengidentifikasi dan merancang kebutuhan dokumen penataausahaan dan pelaporan keuangan yang diperlukan untuk menunjang transparansi dan akuntabilitas pertanggungjawaban keuangan BUMDes.

5. melakukan pendampingan tentang penggunaan dokumen penatausahaan dan pelaporan keuangan BUMDes sehingga pada akhirnya pengelola BUMDes mampu secara mandiri melakukan penatausahaan dan pelaporan keuangan. Melalui pelaporan keuangan yang terdokumentasi dengan baik maka akan memudahkan dalam pengawasan dan pengendalian serta mengevaluasi kemajuan 
dan keberhasilan BUMDes dan mengambil tindakan perbaikan yang diperlukan.
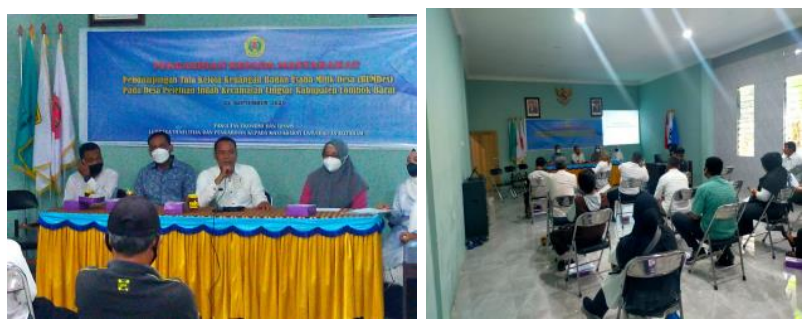

Gambar1.Pengabdian Pendampingan BUMDes

\section{Hasil dan Pembahasan}

Tujuan dari kegiatan pengabdian masyarakat kemitraan ini adalah untuk memberikan pengetahuan dan pendampingan tentang tata kelola keuangan BUMDes. Dengan khalayak sasaran adalah kepala desa dan aparatur desa, pengelola BUMDes dan kelompok masyarakat yang relevan, kegiatan pengabdian kepada masyarakat ini diharapkan dapat memberikan solusi terhadap pengelolaan BUMDes yang lebih baik sebagai bentuk pemberdayaan ekonomi masyarakat desa Peteluan Indah Kecamatan Lingsar Kabupaten Lombok Barat. Untuk menunjang pelaksanaan kegiatan ini dilakukan melalui beberapa tahapan. Tahap pertama, dilakukan pertemuan informal dengan kepala desa dan pengelola BUMDes sebagai bentuk pertemuan awal sehingga diperoleh pemahaman dan persepsi yang sama tentang tujuan dari kegiatan pengabdian kemitraan. Setelah dapat mengetahui permasalahan dalam pengelolaan BUMDes maka tahap kedua adalah merancang kebutuhan dokumen keuangan yang diperlukan dalam penatausahaan dan pelaporan usaha BUMDes, seperti pencatatan transaksi sesuai dengan kaidah akuntansi, penyusunan laporan arus kas, laporan hasil usaha dan laporan posisi keuangan BUMDes. Tahap terakhir dari kegiatan ini adalah, melakukan diskusi dan pendampingan bagi pengelola BUMDes dalam mengimplementasikan kegiatan penatausahaan dan pelaporan keuangan sehingga pada akhirnya pengelola BUMDes dapat menerapkannya secara mandiri. Berikut ini uraian dari masing-masing kegiatan pengabdian kemitraan melalui pendekatan pendampingan BUMDes.

1. Identifikasi Permasalahan BUMDes dengan Pemangku Kepentingan
Kegiatan pengabdian masyarakat ini diawali dengan hasil diskusi awal secara informal dengan pemangku kepentingan desa seperti kepala Desa dan perangkat desa, Badan Permusyawaratan Desa (BPD) dan perwakilan BUMDes tentang keinginan dan harapan agar BUMDes pada Desa Peteluan Indah dapat lebih maju dan dikelola secara transparan, melibatkan peran aktif masyarakat serta dapat dilakukan diversifikasi usaha BUMDes sehingga dapat berkontribusi terhadap pemberdayaan ekonomi masyarakat desa. Menindaklanjuti harapan tersebut maka dilakukan diskusi yang dihadiri kepala desa dan perangkat desa, Badan Pemusyawaratan Desa (BPD), pengelola BUMDes, Kelompok pemuda dan perwakilan masyarakat dalam suatu pertemuan yang dilaksanakan pada kantor Desa Peteluan Indah pada Hari Rabu, 22 September 2021. Kegiatan dilakukan dalam bentuk penyampaian materi tentang tata kelola keuangan BUMDes dari tim pengabdian masyarakat Universitas Mataram, kemudian dilanjutkan dengan diskusi dan tanya jawab dengan peserta rapat terkait dengan permasalahan dalam pengelolaan keuangan BUMDes. Peserta berperan aktif dan responsif dalam mendiskusikan permasalahan pengelolaan BUMDes sehingga pembahasan dapat menghasilkan beberapa hal yang sebagai berikut:

a. usaha BUMdes yang dijalankan relatif terbatas bidang usahanya, terutama hanya berkaitan penjualan pakan ikan sesuai dengan potensi yang dimiliki desa sehingga memberikan pendapatan desa yang terbatas. Terdapat keinginan dari pemangku kepentingan desa untuk mengembangkan potensi desa yang ada dengan melakukan diversifikasi usaha BUMDes yang bisa menambah pendapatan.

b. pengelolaan BUMDes yang saat ini berjalan (penjualan pakan ikan) stagnan tanpa perkembangan usaha yang berarti, sehingga tidak dapat dievaluasi perkembangan kinerja BUMDes.

c. belum adanya sarana untuk melakukan evaluasi dan pengawasan terhadap capaian kinerja BUMDes maupun pertanggungjawaban pengelolaan keuangan BUMDes.

d. adanya ketidakjelasan dan tumpang tindih deskripsi tugas dan kewenangan dalam struktur organisasi antara pengawas, penasehat dan pengelola BUMDes. 
e. tidak adanya bukti transaksi berupa dokumen terhadap aktivitas pengelolaan keuangan BUMDes seperti pembelian aset, pengeluaran dan penerimaan kas.

f. pertanggungjawaban pengelolaan keuangan BUMDes tidak dilakukan secara periodik dalam bentuk pelaporan keuangan seperti laporan hasil usaha, laporan perubahan modal/ekuitas, laporan aset, laporan posisi keuangan maupun laporan arus kas.

g. pengurus Badan Permusyawaratan Desa (BPD) belum memiliki peran yang berarti dalam mendorong kemajuan BUMDes, seperti memberikan saran dan rekomendasi yang dibutuhkan karena keterbatasan pengetahuan dalam pengelolaan operasional maupun keuangan BUMDes.

h. meskipun seringkali mendapatkan kegiatan pelatihan manajemen usaha dan keuangan namun masih rendah komitmen yang tinggi dari pengelola BUMDes dalam menjalankan manajemen administrasi dan tata kelola keuangan BUMDes yang dijalankan secara konsisten.

\section{Perancangan Kebutuhan Dokumen}

Penatausahaan dan Pelaporan Usaha BUMDes.

Berdasarkan permasalahan yang ada dalam pengelolaan usaha dan keuangan BUMDes tersebut maka diberikan langkah-langkah pemecahan masalah sehingga dapat memberikan kontribusi dalam meningkatkan peran BUMDes sebagai lembaga ekonomi desa untuk meningkatkan kesejahteraan masyarakat desa. Adapun pendekatan untuk memecahkan permasalahan dilakukan dalam aspek pembenahan manajemen usaha dan tata kelola keuangan sebagai berikut:

a. pembenahan struktur organisasi dan dekripsi tugas dan kewenangan yang jelas antara pengelola BUMDes, kepala desa dan pengawas dari BPD sehingga tidak terjadi tumpang tindih kewenangan dari masingmasing pihak.

b. penguatan peran dan kemampuan dari anggota BPD yang ditunjuk sebagai pengawas/penasehat dari BUMDes dalam menjalankan kegiatan operasionalnya dan tanggung jawab keuangan pengelolaan BUMDes.

c. perbaikan tata kelola keuangan BUMDes melalui perancangan dokumen-dokumen transaksi yang diperlukan dalam pencatatan transaksi seperti buku aset, buku kas masukkas keluar, buku piutang dan buku utang. Semua transaksi yang telah diverifikasi dan diotorisasi harus dicatat secara kronologis.

d. diperlukan mekanisme pertanggungjawaban dan evaluasi secara periodik terhadap pengelolaan keuangan BUMDes dalam bentuk laporan hasil usaha, laporan perubahan modal/ekuitas, laporan aset, laporan posisi keuangan maupun laporan arus kas.

e. pemberian penguatan positif dan motivasi kepada pengelola BUMDes agar implementasi tata kelola keuangan BUMDes dapat dilaksanakan secara konsisten dan komitmen yang tinggi agar BUMDEs menjadi lembaga ekonomi desa yang semakin berkembang untuk kesejahteraan masyarakat desa.

3. Pendampingan Penatausahaan dan Pelaporan Keuangan BUMDes.

Untuk dapat mengimplementasikan tata kelola keuangan secara mandiri, pengelola BUMDes harus memiliki pengetahuan yang memadai tentang menjalankan kegiatan operasional usaha, penatausahaan dan pelaporan keuangan BUMDes. Kegiatan pendampingan ini dilakukan fokus pada aspek kelembagaan, pemilihan usaha, manajemen usaha dan tata kelola keuangan yang diuraikan sebagai berikut:

(1) Penguatan Kelembagaan BUMDes

BUMDes harus memiliki struktur organisasi dan deskripsi tugas dan kewenangan yang jelas diantara fungsi pelaksana operasional, penasehat dan pengawas. Pengelola atau pengurus BUMDes dipilih dalam suatu musyawarah desa dan bertanggungjawab menjalankan kegiatan operasional BUMDes. Kewenangan dari pengurus BUMDes adalah melaksanakan dan mengembangkan BUMDes agar menjadi lembaga yang melayani kebutuhan ekonomi dan/atau pelayanan umum masyarakat Desa; menggali dan memanfaatkan potensi usaha ekonomi Desa untuk meningkatkan Pendapatan Asli Desa; dan melakukan kerjasama dengan lembaga-lembaga perekonomian desa lainnya. Adapun kewajiban dari Pengurus BUMDes adalah membuat laporan keuangan seluruh unit-unit usaha BUMDes setiap bulan, laporan perkembangan kegiatan unit-unit usaha BUMDes setiap bulan dan memberikan laporan perkembangan unit-unit usaha BUMDes 
kepada masyarakat desa melalui Musyawarah Desa sekurang-kurangnya 2 (dua) kali dalam 1 (satu) tahun.

Dalam menjalankan kegiatannya, BUMDes akan diawasi oleh pengawas yang terdiri dari ketua dan anggota yang berasal dari Badan Permusyawaratan Desa (BPD) yang dipilih melalui musyawarah desa. Pengawas bertugas mengawasi semua kegiatan dan memberikan nasihat kepada pelaksana operasional atau direksi dalam menjalankan kegiatan pengelolaan usaha desa. Kewenangan pengawas antara lain adalah pengangkatan dan pemberhentian pengurus atau pelaksana operasional, meminta Laporan rincian laporan hasil usaha (laba rugi) dan laporan posisi keuangan dan penjelasan-penjelasan atas pelaksanaan kegiatan BUMDes; serta meminta laporan pertanggungjawaban pelaksana operasional setiap akhir tahun.

Kepala Desa secara ex officio akan menjabat sebagai penasehat pada struktur BUMDes. Kewenangan Kepala Desa sebagai penasehat pada Struktur BUMDes adalah meminta penjelasan dari pelaksana operasional mengenai persoalan yang menyangkut pengelolaan usaha desa dan melindungi usaha esa terhadap hal-hal yang dapat menurunkan kinerja BUMDes. Adapun kewajiban dari kepala desa sebagai penasehat BUMDes adalah memberikan nasihat kepada pelaksana operasional dalam melaksanakan pengelolaan BUMDesa, memberikan saran dan pendapat mengenai masalah yang dianggap penting bagi pengelolaan BUMDesa dan mengendalikan pelaksanaan kegiatan pengelolaan BUMDesa.

(2) Pemilihan Usaha Sesuai dengan Potensi Keunggulan Desa

Bagi desa yang telah memiliki usaha BUMDes yang telah berjalan perlu dapat dilakukan pengelolaan manajemen usaha sehingga dapat mencapai kinerja BUMDes yang diharapkan. Termasuk dalam hal ini adalah komitem dari pengelola BUMDes dalam menjalankan oleh tata kelola keuangan BUMDes sebagai mekanisme pertanggungjawaban dan pengelolaan BUMDEs yang transparan dan akuntabel. Pemilihan usaha BUMDes sebaiknya berbasis potensi unggulan yang dimiliki desa sehingga dapat melibatkan peran aktif dari masyarakat. Pada Desa Peteluan Indah yang memiliki keunggulan dalam bidang perikanan sehingga pemilihan usaha penyaluran pakan ikan menjadi pilihan yang tepat. Namun demikian perlu dilakukan diversifikasi usaha BUMDes lainnya sehingga dapat berpotensi meningkatkan pendapatan BUMDes. Salah satu gagasan yang dapat ditindaklanjuti adalah membuat usaha yang bisa memberikan nilai tambah (value added) dari hasil unggulan desa berupa ikan hasil budidaya yang hasilnya melimpah dalam bentuk ikan olahan (seperti sarden, ikan panggang, abon ikan) yang memungkinkan produk hasil olahan ikan dapat disimpan dalam waktu yang lebih lama terutama ketika panen raya terjadi. Dengan membuat diversifikasi usaha ikan olahan diharapkan dapat melakukan pemberdayaan ekonomi dan meningkatkan kesejahteraan masyarakat desa.

(3) Manajemen Usaha

Untuk menunjang keberhasilan BUMDes dibutuhkan manajemen usaha yang meliputi pengelolaan kegiatan operasional harian, merancang strategi untuk memperluas usaha dan strategi pemasaran jasa/produk, pengelolaan potensi ekonomi dan alokasi sumberdaya dengan tepat serta peningkatan kemampuan Sumber Daya Manusia (SDM) pengelola BUMDes. Manajemen usaha ini dapat dilakukan secara konsisten oleh pengurus BUMDes karena perubahan lingkungan bisnis yang dinamis sehingga perlu secara berkelanjutan mengevaluasi hambatan-hambatan dan strategi-strategi yang diperlukan dalam mengatasi permasalahan yang terjadi.

(4) Pengelolaan Keuangan

Permendesa PDTT Nomor 4 Tahun 2015 menyatakan bahwa pengelolaan BUMDes mencakup 4 tahapan yaitu penganggaran, penatausahaan, pelaporan dan pengendalian internal. Melalui proses pertanggungjawaban dan evaluasi terhadap keberhasilan usaha BUMDes dan pengelolaan keuangan maka dapat dinilai kinerja BUMDes dan rencana-rencana pengembangan usaha yang belum terealisasi. Hal ini juga menjadi dasar untuk tindakan pengawasan dan pengendalian yang diperlukan. Penatausahaan dan pelaporan keuangan BUMDes dapat dilakukan dengan penyusunan dokumen pencatatan transaksi sesuai dengan kaidah akuntansi, seperti bukti transaksi dan otorisasi, semua bukti transaksi harus dicatat dalam buku catatan akuntansi usaha, pembuatan buku penerimaan/pengeluaran kas, buku piutang/utang, buku aset tetap dan buku transaksi lainnya yang diperlukan. Secara berkala dapat dilakukan perhitungan saldo akhir untuk masing-masing akun (bulanan/triwulan/kuartal/semester/tahunan). 
Laporan keuangan BUMDes dibutuhkan sebagai bentuk pertanggungjawaban terhadap pengelolaan operasional BUMDes, sarana evaluasi keberhasilan usaha serta dasar tindakan korektif dan solusi permasalahan yang diperlukan. Adanya laporan usaha juga menunjang transparansi dan akuntabilitas pengelolaan BUMDes. Laporan keuangan BUMDes dapat berupa penyusunan laporan keuangan seperti laporan hasil usaha, laporan arus kas, laporan perubahan ekuitas dan laporan posisi keuangan. Melalui pengetahuan dan pendampingan tentang cara pemanfaatan dokumendokumen keuangan tersebut dapat menunjang penatausahaan dan pelaporan usaha untuk pertanggungjawaban pengelolaan keuangan BUMDes, evaluasi capaian kinerja usaha maupun tindakan pengendalian dan pengawasan yang diperlukan. Dengan demikian diharapkan pada akhirnya pengelola BUMDes dapat secara mandiri melakukan penatausahaan dan pelaporan keuangan untuk mewujudkan best practices dalam tata kelola keuangan BUMDes.

\section{Kesimpulan}

Evaluasi terhadap pengelolaan BUMDes membutuhkan mekanisme pengawasan dan pertanggungjawaban pengelolaan keuangan dengan menggunakan dokumen-dokumen dan pelaporan untuk menunjang akuntabilitas pengelolaan keuangan BUMDes. Permasalahan dalam tata kelola keuangan BUMDES terutama berkaitan dengan ketidakjelasan struktur organisasi dan deskripsi tugas serta kewenangan antara pengelola dan pengawas, tidak tersedianya dokumen pendukung dan pelaporan keuangan untuk mengevaluasi kinerja pengelolaan BUMDes dan pertanggungjawaban pengelola. Melalui kegiatan pendampingan tata kelola keuangan BUMDes dapat didapat dirancang dokumen dan pelaporan yang dibutuhkan dalam pengelolaan keuangan BUMDes. Dokumen pencatatan transaksi keuangan harus didukung oleh bukti transaksi yang sah, dilakukan secara kronologis serta telah diverifikasi dan diotorisasi. Secara periodik perlu dilakukan evaluasi dan pengawasan terhadap kinerja BUMDes dalam bentuk pelaporan pertanggungjawaban pengelolaan keuangan BUMDes, berupa laporan hasil usaha, laporan perubahan ekuitas/modal, laporan posisi keuangan serta laporan arus kas. Komitmen tinggi yang dilaksanakan secara konsisten oleh pengelola BUMDEs diperlukan untuk menjalankan penatausahaan dan tata kelola keuangan sehingga bermanfaat menunjang akuntabilitas dan keberhasilan BUMDES dalam jangka panjang.

\section{Saran}

mampu Kegiatan pengabdian masyarakat ini permasalahan yang terjadi dalam pengelolaan BUMDes terutama yang berkaitan dengan tata kelola keuangan yang sebagai bentuk mekanisme pertanggungjawaban dan evaluasi terhadap keberhasilan pengelolaan BUMDes. Melalui kegiatan pendampingan pengelola BUMDes dapat menjalankan kegiatan operasional BUMDes yang didukung oleh dokumen dan pelaporan keuangan pengelolaan yang memadai untuk kebutuhan evaluasi kinerja dan pertanggungjawaban. Oleh karena itu, ke depan pelaksanaan penatausahaan keuangan dan pelaporan pertanggungjawaban keuangan yang dilaksanakan secara konsisten dapat menunjang keberlangsungan BUMDes dalam jangka panjang. Untuk pengembangan BUMdes, disarankan juga untuk membuka peluang-peluang usaha baru sesuai dengan potensi unggulan yang dimiliki desa. Dengan demikian, keberadaaan BUMDes dapat berkontribusi sebagai lembaga ekonomi desa untuk pemberdayaan ekonomi dan peningkatan kesejahteraan masyarakat desa.

\section{Ucapan Terima Kasih}

Penulis mengucapkan terima kasih kepada Lembaga Penelitian dan Pengabdian Masyarakat (LPPM) Universitas Mataram, yang telah memberikan dukungan dana untuk melaksanakan kegiatan pengabdian masyarakat melalui Dana DIPA BLU (PNBP) Universitas Mataram Tahun Anggaran 2021.

\section{Daftar Pustaka}

Agunggunanto, E. Yusuf; Fitrie Arianti, Edi Wibowo Kushartono, Darwanto. 2016. Pengembangan Desa Mandiri Melalui Pengelolaan Badan Usaha Milik Desa (BUMDES). Jurnal Dinamika Ekonomi dan Bisnis, 13, (7), 67-81. 
Dwiningwarni, S.S. \& Amrulloh, A.Z. 2020. Peranan pengelolaan dana desa untuk meningkatkan pendapatan masyarakat di Jombang Jawa Timur. Ekuitas: Jurnal Ekonomi dan Keuangan 4, (1), 1-20. DOI: 10.24034/j25485024.y2020.v4.i1.4128

Irawati, Dina. \& Martanti, Diana. E. 2017. Transparansi pengelolaan laporan keuangan BUMDes terhadap pelaporan aset desa (Studi fenomenologi pada BUMDes Desa Karangbendo Kec Ponggok Kab Blitar. Prosiding Seminar Nasional dan Call For Paper Ekonomi dan Bisnis (SNAPER-EBIS 2017) - Jember, 27-28 Oktober 2017, hal 41-51.

Musafa,. Hernawan,Y. \& Dewi,S. W.K. 2018. Workshop Manual \& Digital Accounting Pada Badan Usaha Milik Desa Girimekar. Jurnal Pengabdian Masyarakat BSI, 1, (2), 322-333

Nasrulhaq, Akfa. 2019. Hingga 2018, 61 persen desa di Indonesia sudah punya BUMDes. https://news.detik.com/berita/d4526846/hingga-2018-61-persen-desa-diindonesia-sudah-punya-bumdes. Diakses pada 10 Februari pukul 11.55

Oktaviani, L. \& Nusawantara, D.A. 2020. Keterterapan prinsip-prinsip pengendalian internal dalam tata kelola Badan Usaha Milik Desa (BUM Desa) di Kabupaten Sidoarjo. Matra Pembaharuan: Jurnal Inovasi Kebijakan 4, (2), 83-92

Peraturan Menteri Desa dan PDT Nomor 13 Tahun 2020 Tentang Prioritas Penggunaan Dana Desa Tahun 2021

Peraturan Menteri Desa dan PDT Nomor 4 Tahun 2015 tentang Pendirian, Pengurusan, dan Pengelolaan, dan pembubaran Badan Usaha Milik Desa

Resti, Ayu. 2019. Prosedur Pengelolaan Keuangan BUMDes. https://blog.bumdes.id/2019/08/prosedurpengelolaan-keuangan-bumdes/. Diakses pada 21 Februari 2021 pukul 11.20
Ridwan, M.F. \& Putri, W.D. 2016. Desa di NTB banyak yang belum miliki BUMDes. https://nasional.republika.co.id/berita/nasio nal/daerah/octed9359/desa-di-ntb-masihbanyak-yang-belum-miliki-bumdes. Diakses pada 18 Februari 2021 pukul 16.19

Titioka, B.M., Huliselan, M., Sanduan, A., Ralahallo, F.N. \& Siahainenia, A.J.D. 2020. Pengelolaan keuangan BUMDes di Kabupaten Kepulauan Aru. Jurnal Pengabdian Masyarakat Manajemen dan Akuntansi 3, (1), 197-216.

Undang-undang Nomor 6 tahun 2014 tentang Desa 